\title{
DETECTION AND MAPPING OF ARSENIC CONTAMINATION IN BANGLADESH
}

\author{
P. Basak ${ }^{1}$, H. Rashid ${ }^{2}$, F. M. Mohee ${ }^{3}$, M. Freire-Gormaly ${ }^{4 *}$ \\ ${ }^{1}$ Faculty of Environmental Science \& Policy, Central European University, Budapest, Hungary \\ ${ }^{2}$ Environmental Sciences, Asian University for Women (AUW), Chittagong, Bangladesh \\ ${ }^{3}$ Faculty of Applied Science and Engineering, University of Toronto, Canada \\ ${ }^{4}$ Department of Mechanical Engineering, York University, Canada \\ * marina.freire-gormaly@lassonde.yorku.ca
}

\begin{abstract}
Arsenic contamination in the groundwater of Bangladesh is of major concern due to the high reliance on groundwater for drinking water, large levels of groundwater extraction for agricultural purposes and the impact of climate change depleting the groundwater table. Although the Sitakunda Distract was earlier considered to be free from Arsenic contamination, recent experimental data shows the Sitakunda District has high Arsenic concentrations. The objective of this work was to identify the Arsenic affected wells in the Sitakunda District, Chittagong, map them in QGIS mapping software and updated Bing imagery using GPS coordinates from GPS Devices and to explore the potential relationship between the present data with past data. The Sitakunda District region wells examined in this study determined the Arsenic concentration to be in the range of $100-500+$ ppb which is much higher than the World Health Organization limits (10 ppb) and Bangladesh limit (50ppb). The generated maps in QGIS showed the randomly selected tested tubewells with satellite imagery and their corresponding elevation, yet no precise correlation between Arsenic contamination and land elevation was determined. The results of this study and corresponding satellite map has the potential to identify Arsenic contaminated tubewells for the community members. Future investigations will explore the development of suitable low-cost water treatment technologies to remove the Arsenic contamination.
\end{abstract}

\section{Arsenic contamination; GIS; Mapping; Groundwater}

\section{INTRODUCTION}

Arsenic is an element that occurs naturally and is widely distributed in the crust of the earth. In the environment, arsenic is combined with oxygen, chlorine, and sulfur to form inorganic arsenic compounds. These forms are usually in complex form but when the bonds between these complex molecules break, arsenic can be free and be mixed with both soil and water.

Drinking water which has high level of arsenic for a long period, leads to arsenic poisoning or the disease named arsenicosis and many more other diseases such as, lung cancer. Because of these catastrophic impacts, it is very crucial to test and determine if any groundwater plate is contaminated with arsenic or not. Though the tests of arsenic can be done and presented through statistics, in an area, it is significant to represent these results in a visual form that can be understandable to the common people and policy makers.

GIS mapping is one effective method to provide policy makers and local officials concrete data on the location of the . The abbreviation of "GIS" is "Geographic Information System" and "Mapping" refers to the process of making maps. GIS Mapping is the process of making maps of geographic locations or coordinates.

Through the process of mapping we can identify many issues of different areas of studies such as, environmental issues, natural disasters, infrastructure problems and so on. This work used GIS mapping for locating arsenic affected wells in areas of Sitakunda so that safe water can be supplied to the households and people of the Barayadala, Sitakunda community and also try to see if there is any relation between land elevation and concentration of arsenic in the water through mapping.

\section{LITERATURE REVIEW}

Bangladesh has been facing issues with arsenic in the groundwater for decades. During the mid-1960s, the life expectancy at Bangladesh was 46 years [1]. This low rate was due to the occurrence of premature deaths in the country caused by life-threatening diseases such as, diarrhea, cholera, typhoid and many others which occurred from surface water intake [1].

To solve these issues, the aid agencies, governments of Bangladesh and private individuals came forward with the idea of constructing deep tube wells across the country. They started to construct 8-12 million deep tubewells across the country for providing microbial free safe drinking water to the people [2]. By the year 1995, there were $97 \%$ people of Bangladesh, out of 120 million, who were drinking water from these tubewells [3]. Currently, Arsenic contamination continues to be a public health challenge in Bangladesh [4]. 
Although the people survived from the microbial diseases due to drinking water from deep tube-wells, an unexpected problem of arsenic contamination arose. Since heavy metals in the aquifers were not anticipated, nor identified during construction. In 1993, the first case of arsenic poisoning was detected in Dhaka Community Hospital [5]. In 1997, the first national-scale map of As concentration in Bangladesh's groundwater was produced which showed that $45 \%$ of the areas of Bangladesh had arsenic concentrations greater than $50 \mu \mathrm{g} / \mathrm{L}$ which is the national standard [6].

Another risk assessment which was done in 2003 showed that 28 million people of Bangladesh were drinking deep tube well water that exceeded national standard [7]. This chronic exposure of As resulted in skin cancer, arsenicosis, melanosis, leukomelanosis, keratosis, hyperkeratosis and nonpitting edema $[6,8]$. Due to these reasons, it became a necessity to measure and monitor Arsenic in the constructed tubewells.

\section{A. Justification of the Study}

Arsenic poisoning in drinking water in Bangladesh has already been identified as one of the world's greatest humanitarian disasters. According to Chemist without Borders, an international organization which has been working with arsenic issues of Bangladesh for years, 35-77 million people are at risk from arsenic contamination of water out of 150 million people of Bangladesh. It is estimated that at least 1-5 million children are at risk of death by arsenicosis by 2030 [9]. So, this problem needs to be brought into serious consideration as soon as possible. Because of all these reasons, it is very important for the citizens and governments of Bangladesh to know the places and wells which are arsenic contaminated.

Studies for improved water treatment can be used to address the Arsenic contamination [10] based on the presence of Arsenic contamination. The Arsenic contamination can also permeate between the soils, groundwater system and rock structures, therefore, a thorough understanding of the porous rock and soil structures [11-14] in Bangladesh are needed. Rapid structures to support the water treatment systems composed of carbon fibre reinforced fibre structures [15-18] can also be used. Furthermore, the impacts of climate change are likely to exacerbate the challenge of Arsenic contamination in soils [29-33].

This case study shows field data from deep tubewells from Sitakunda area that have identified arsenic contamination. The data will also be converted to visual representation as maps which will help the government and non-government organization to locate the affected areas and plan for providing safe drinking water delivery routes for the people living in that community.

\section{METHODOLOGY}

The area of Sitakunda is vast and so an area needed to be chosen for the research. Based on secondary data from Chemist without Borders, the area of Bariadyala was chosen for the study area (Figure 1).

A series of measurements were made of the Arsenic from the tubewells in the Bariadyala area using Hatch Kits. The Arsenic levels were above both the WHO limit and the Bangladesh limit. In the elevation map (Figure 2), the variation of concentrations is shown to be non-correlated with elevation in this specific Bariadyala area.

Mapping for finding toxic metals has been previously done for different countries. Peng et al. [33] have recently done similar mapping projects for the soils of Qatar. Peng et al.'s research [33] focused on different parameters (soil and groundwater), the mapping approach outlined here are similar.

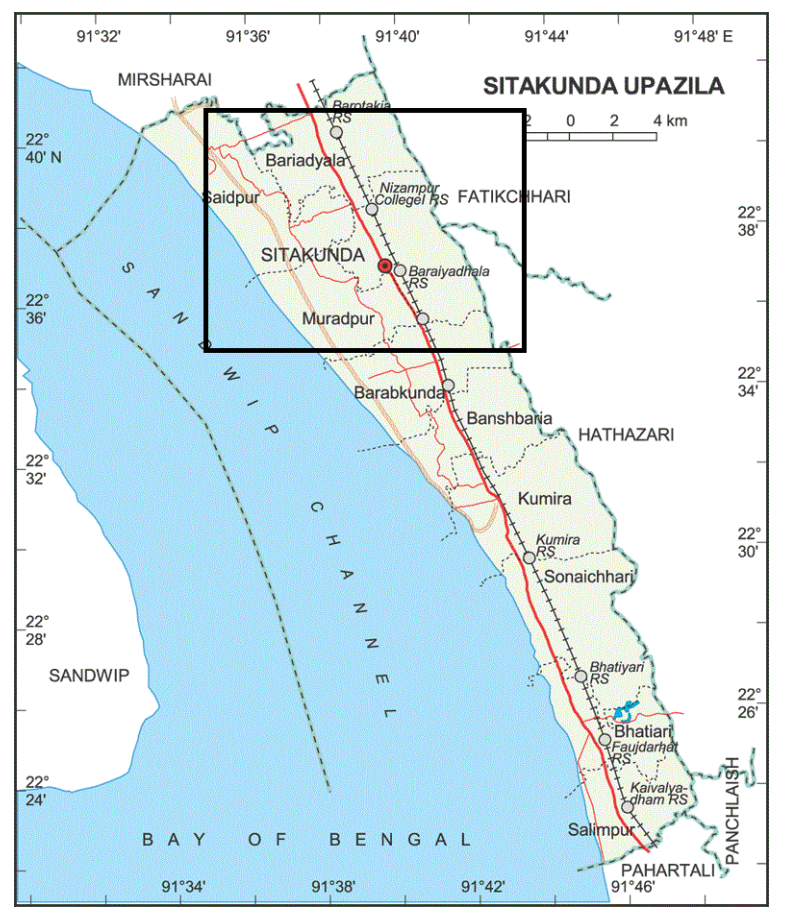

Figure 1. Map of the Bariadyala area in the the Sitakunda District, Chittagong, Bangladesh

\section{RESULTS AND DISCUSSION}

The results from this study, which measured the concentration of Arsenic in the Bariadyala area of the Sitakunda District, show many wells are above the limits from WHO (which is $10 \mathrm{ppb}$ ) and Bangladesh (which is $50 \mathrm{ppb}$ ). The percentage of wells with Lower concentration (0-200 ppb) was $40.63 \%$, Medium Concentration (200-300 ppb) was $25.00 \%$ and High Concentration (301-500 ppb) was $31.25 \%$. Figure 2 shows how the arsenic concentration related to the elevation of the land.

The purpose behind collecting the elevation data was to see if there were any relationship between the Arsenic on the ground with its elevation. There appears to be no direct correlation between the elevation and the concentration. Further studies are required to identify the spread of the arsenic 
contamination, to select appropriate remediation measures, and to investigate the impact of the arsenic on the health of residents and the safety of the food grown in these regions.

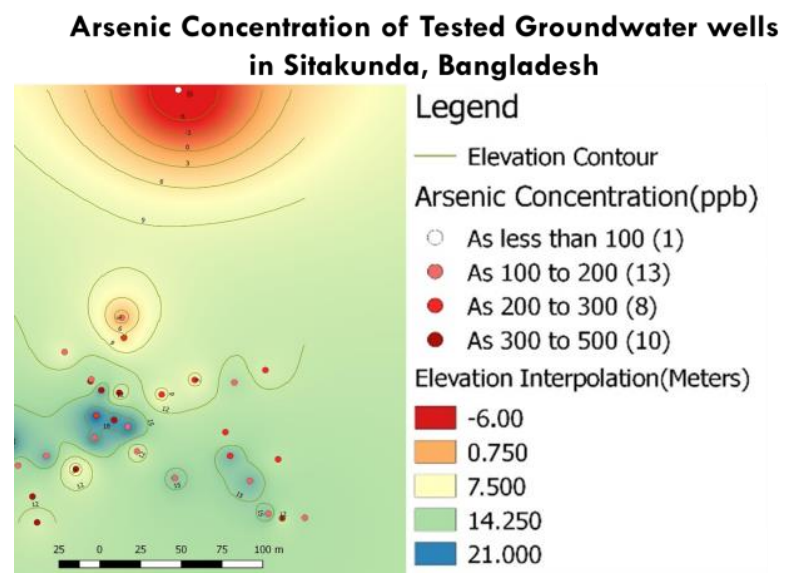

Figure 2. Arsenic contamination in the Bariadyala area tubewells

\section{CONCLUSIONS}

In this case study, the concentration of Arsenic was measured for the Bariadyala area of the Sitakunda District and shown using QGIS maps. Although no direct relationship between land elevation and arsenic concentration was found, further research can investigate the correlation of the Arsenic levels in the water and soil in the broader Sitakunda region.

The results of this research can impact the lives of 3.5 Million people living in Sitakunda, 92\% of which drink tubewell water. The data derived from this research and the generated maps can be used by environmental authorities and land managers for identifying solutions to treat Arsenic contamination. Future work will focus on low-cost means of treating Arsenic contamination in drinking and irrigation water for these communities.

\section{ACKNOWLEDGMENT}

The authors are grateful for the collaboration with volunteers from Chemists Without Borders. The authors are thankful to the Natural Sciences and Engineering Research Council (NSERC) of Canada for the NSERC Discovery Grant.

\section{REFERENCES}

[1] R. F. Nyrop, B. L. Benderly, C. C. Conn, W. W. Cover, D. R. Egiin, Area Handbook of Bangladesh. Washington, DC:American University, 1975.

[2] WHO, Fact Sheet \#210: Arsenic in Drinking Water. Available: http://www.who.int/inf-fs/en/fact210.html, 2003.

[3] WHO, Arsenic Contamination of Drinking Water in Bangladesh. Available:

http://www.who.int/bulletin/archives/78\%289\%291093.pdf?ua=1\#: :tex $\mathrm{t}=\mathrm{A} \% 20$ recent\%20report\%20from\%20the,have\%20arsenic\%2Dinduced \%20skin\%20lesions. , 2000.

[4] S. A. Ahmad, M. H. Khan, M. Haque, Arsenic contamination in groundwater in Bangladesh: implications and challenges for healthcare policy. Risk management and healthcare policy, 11, 251-261. https://doi.org/10.2147/RMHP.S153188, 2018.

[5] BGS, Groundwater Studies for Arsenic Contamination in Bangladesh, Main Report. Nottingham, UK:British Geological Survey, 1999.

[6] S. H. Frisbie, R. Ortega, D. M. Maynard, B. Sarkar, The Concentrations of Arsenic and Other Toxic Elements in Bangladesh's Drinking Water, Environmental Health Perspectives, Vol. 110, Issue 11, pg. 1147-1153, 2002.

[7] W. H. Yu, C. M. Harvey, and C. F. Harvey, Arsenic in groundwater in Bangladesh: A geostatistical and epidemiological framework for evaluating health effects and potential remedies, Water Resources Research, 39(6), 1146, doi:10.1029/2002WR001327, 2003.

[8] I. Mihajlov, M. R. H. Mozumder, B. C. Bostick, et al. Arsenic contamination of Bangladesh aquifers exacerbated by clay layers. Nat Commun 11, 2244 https://doi.org/10.1038/s41467-020-16104-z, 2020.

[9] M. Schur, Chemists Without Borders Bangladesh Arsenic Education. Available: https://www.indiegogo.com/projects/chemists-withoutborders-bangladesh-arsenic-educ-n\#l, 2014.

[10] M. Freire-Gormaly, Experimental Characterization of Membrane Fouling under Intermittent Operation and Its Application to the Optimization of Solar Photovoltaic Powered Reverse Osmosis Drinking Water Treatment Systems. University of Toronto, 2018.

[11] M. Freire-Gormaly, The Pore Structure of Indiana Limestone and Pink Dolomite for the Modeling of Carbon Dioxide in Geologic Carbonate Rock Formations. University of Toronto. Retrieved from http://hdl.handle.net/1807/42840, 2013.

[12] M. Freire-Gormaly, A. Bazylak, H. L. Maclean, Microct Investigations and pore network reconstructions of limestone and carbonate-based rocks for deep geologic carbon sequestration, ASME 2012 6th International Conference on Energy Sustainability collocated with the ASME 2012 10th International Conference on Fuel Cell Science, Engineering and Technology, American Society of Mechanical Engineers, pp. 863-866, 2012.

[13] M. Freire-Gormaly, J. S. Ellis, A. Bazylak, H. L. Maclean, Pore Network Reconstructions and Pore-Scale Characterization of Limestone and Carbonate-Based Rocks for Deep Geologic Carbon Sequestration. In 223rd ECS Meeting, 157, 2012.

[14] M. Freire-Gormaly, J. S. Ellis, A. Bazylak, H. L. MacLean, Comparing thresholding techniques for quantifying the dual porosity of Indiana Limestone and Pink Dolomite. Microporous and Mesoporous Materials, 207, 84-89. https://doi.org/10.1016/j.micromeso.2015.01.002, 2015.

[15] F. M. Mohee, A. Al-Mayah, A. Plumtree, Friction Characteristics of CFRP Plates in Contact with Copper Plates under High Contact Pressure. Journal of Composites for Construction, 4016022. https://doi.org/10.1061/(ASCE)CC.1943-5614.0000673 , 2016.

[16] F. M. Mohee, Development, Analysis and Testing of Innovative Mechanical Prestressing Anchors for CFRP Plates for Structural Rehabilitation and Retrofitting. University of Waterloo (UWSpace). Retrieved from http://hdl.handle.net/10012/11207, 2017.

[17] F. M. Mohee, A. Al-mayah, Effect of modulus of elasticity and thickness of the CFRP plate on the performance of a novel anchor for structural retrofitting and rehabilitation applications. Engineering Structures, 153, 302-316, https://doi.org/10.1016/j.engstruct.2017.09.057, 2017.

[18] F. M. Mohee, A. Al-Mayah, Development of an innovative prestressing CFRP plate anchor: Numerical modelling and parametric study. Composite Structures, 177, 1-12, https://doi.org/10.1016/j.compstruct.2016.12.039, 2017.

[19] F. M. Mohee, A. Al-Mayah, Effect of barrel, wedge material and thickness on composite plate anchor performance through analytical, finite element, experimental and 3D prototype investigations. Engineering Structures, 175, 138-154, https://doi.org/10.1016/j.engstruct.2018.08.003, 2018.

[20] A. Hoque, F. Kamal, F. M. Mohee, M. Haque, M. Hossain, Fluoride, Magnesium, and Sodium in dental chewing stick plants used in Bangladesh. Fluoride, 40(1), 24-30, 2007.

[21] F. Kamal, N. Ahmed, F. M. Mohee, M. Abedin, A. Shariff, A. Saadat, A. Hoque, Trace element analysis in soil samples of Hazaribagh tannery area by PIXE. Journal of Environmental Science, 5, 31-36, 2007. 
[22] F. M. Mohee, A. Al-Mayah, Towards A Mechanical Anchor System For CFRP Plates, Canadian Society of Civil Engineers (CSCE) 2017 Annual Conference, Vancouver, Canada, 2017.

[23] F. M. Mohee, A. Al-Mayah, A. Plumtree, Anchors for CFRP plates: State-of-the-art review and future potential. Composites Part B: Engineering, 90, 432-442. https://doi.org/10.1016/j.compositesb.2016.01.011, 2016.

[24] F. M. Mohee, A. Al-Mayah, A. Plumtree, Development of a novel prestressing anchor for CFRP plates: Experimental investigations. Composite Structures, 176, 20-32. https://doi.org/10.1016/j.compstruct.2017.05.011, 2017.

[25] F. M. Mohee, The Effects of Strain Rate on Concrete Strength under Dynamic Impact Load, Journal of Bangladesh Electronics Society, 16, 2016.

[26] F. M. Mohee, F. M. Kamal, Ground Response Spectra for Different Damping Values for $0.3 \mathrm{~g}$ Peak Ground Acceleration Earthquake in Bangladesh, Journal of Bangladesh Electronics Society, 17, 2017.

[27] F. M. Mohee, F. M. Kamal, Application of High-strength Composite Materials for the Nuclear Waste Containers and Flasks, Canadian Society of Civil Engineers (CSCE) 2017 Annual Conference, Vancouver, Canada, 2017.

[28] F. M. Mohee, F. M. Kamal, Manufacturing of Nuclear Waste Containers and Flasks: Consideration of Transportation Load, Acceleration Load and Fatigue Load: a Structural Engineering Perspective, 36th Annual Conference of the Canadian Nuclear Society 40th Annual CNS/CNA Student Conference, 2016 June 19 - 22, Marriott Toronto Eaton Centre Hotel, Toronto, Canada, 2016.

[29] F. M. Mohee, A review of the Effects and Control of the Mercury Emissions from Cement industry, EIC - Climate Change Technology Conference 2013, Montreal, Canada, 2013.

[30] F. M. Mohee, C. Miller, Climatology of thunderstorms for North Dakota, 2002-06. Journal of Applied Meteorology and Climatology, 49(9), 1881-1890. https://doi.org/10.1175/2010JAMC2400.1, 2010.

[31] F. M. Mohee, Usage of Radar reflectivity data and Surface speed data for the prediction of climate change patterns in Bangladesh, International Conference on Climate Change Impacts and Adaptation Strategies for Bangladesh, 2019.

[32] F. M. Mohee, Development of a radar based thunderstorm climatology for North Dakota, 24th Conference on Severe Local Storms, American Meteorological Society (AMS), GA, USA. Retrieved from https://ams.confex.com/ams/24SLS/techprogram/paper_142135.htm , 2008.

[33] Y. Peng, R. Kheir, K. Adhikari, R. Malinowski, M. Greve, M. Knadel, M. Greve, Digital Mapping of Toxic Metals in Qatari Soils Using Remote Sensing and Ancillary Data. Remote Sensing, 8(12), 1003. doi:10.3390/rs8121003G, 2016. 